\title{
Product returns: a growing problem for business, society and environment
}

\begin{tabular}{|r|l|}
\hline Journal: & International Journal of Operations and Production Management \\
\hline Manuscript ID & IJOPM-02-2020-0083.R1 \\
\hline Manuscript Type: & Impact Pathways \\
\hline Keywords: & $\begin{array}{l}\text { Retail sector, Reverse logistics, Supply chain management, Business } \\
\text { strategy, Sustainability, Operations strategy }\end{array}$ \\
\hline \multicolumn{2}{|l}{} \\
\hline
\end{tabular}

\section{SCHOLARONE" \\ Manuscripts}




\title{
Product returns: a growing problem for business, society and environment
}

\begin{abstract}
Purpose: This article sheds light onto the increasing problem of product returns, which is exacerbated by growing eCommerce. Many retailers and academics are oblivious to the nature and scale of this challenge. Interdisciplinary research is needed to develop supporting theory and cross-functional teams are required to implement measures addressing economic, ecological and social sustainability issues.
\end{abstract}

Design/methodology/approach: The initial project adopted a multi-case study approach, whereby returns processes were mapped, vulnerabilities identified and a returns cost calculator was developed.

Findings: Product returns processes are usually complicated, prone to internal and external fraud, inefficient and lack sustainability. They can generate considerable losses to the business, especially as returns data are often not systematically collected, monitored or reported to senior management. There are important implications for strategic and operational management, namely the need to develop a concept for Lean returns systems.

Originality/value: Product returns are a unique and understudied but growing field in academic research, with only few publications over the last two decades. Yet the phenomenon is causing increasing problems in business and society. Robust solutions could achieve great financial and non-financial impacts.

\section{Introduction and background}

In the current economic climate, many retailers are struggling to survive. Product returns are one of the major factors that contribute to this struggle, partially because many retailers underestimate the scale of the problem, and partially because there is not enough support available in terms of frameworks and guidelines. Importantly, there is no concept yet of Lean systems in product returns.

Consumption is at an all-time high (Institute for European Environmental Policy, 2019) yet, at the same time, highstreets are suffering: many shops are closing, and even major chains go into administration. Communities are losing their lively town centres, and many retail jobs are lost. With Internet sales growing strongly, many retailers aspire to become omnichannel, integrating their online and physical shopping outlets. Great customer service is seen as a cornerstone of the omnichannel experience, and as driving sales. Therefore, most retail businesses offer free delivery and multiple ways of returning items, often without charge - including return to store of items sold online. However, the downside has been the unanticipated number of returns generated; typical returns rates are $20-40 \%$ with certain businesses reporting up to $70 \%$ according to the Financial Times (Ram, 2016). With this 'free returns' offering to customers, many businesses are unclear about the true costs of returns to the business and specifically, the extent to which this policy is being abused, leading to retail loss (redacted for review: project report). Appriss Retail (Speights, 2013) reported that:

"Of the 10 retail clients under study, all were found to be underestimating their return rate - one by as much as $150 \%$, with an average return rate discrepancy of over $80 \% \ldots$ resulting in additional costs of over [US] $\$ 462$ million to a retailer doing $\$ 10$ billion in annual revenue." 
Even a small improvement in return rates and associated costs can directly improve the bottom line. For an average company, we estimate that even a $5 \%$ improvement in the rate of returns has the potential to deliver a 200 Basis Points improvement in net margin.

Product returns are not just an economic problem; they are also massively damaging to the environment. According to Vogue Business (Schiffer, 2019):

"US returns alone create 5 billion pounds of landfill waste and 15 million tonnes of carbon emissions annually, equivalent to the amount of trash produced by 5 million people in a year".

Building upon published research, the authors of this article conducted a research project on product returns for an association of European retailers and manufacturers who are interested in understanding the scale and importance of product returns, their true costs, the challenges and vulnerabilities in the currently used returns systems, best practice, and opportunities for improvement, including ways to become more sustainable economically and ecologically. The research consisted of a comprehensive investigation involving a desk study of 100 retailers' online returns policies; a review of other existing studies; four in-depth case studies with major UK retailers, including over 25 interviews, observations and site visits; and structured interviews with another 17 retailers in the UK and Europe. It is the first thorough study on product returns in a multichannel retail environment (redacted for review: project report).

\subsection{Understanding the problems}

Our case studies show that returns of purchases (including stock that became obsolete, outdated or damaged anywhere along the forward or reverse supply chain) cause significant issues, both in terms of environmental sustainability and financially for retailers. These will then need to recover increasing costs from customers by increasing product prices, so customers lose out as well. Whilst "free" returns incentivise customers to order more and return more, retailers struggle to process all these products returned in various states. Typically, processes are far from streamlined; product flows are organised adhoc, and data are recorded or transferred manually. From storefront via back-of-store to (returns) distribution centres - (R)DCs, IT systems suffer from patchy integration, and the inability to communicate with each other is clearly evident. Items are shipped from stores to $(R) D C$ s and may be further damaged, stolen, or take a long time to arrive. At the (R)DC, products need to be assessed, logged and sent onto the right path, be it back to sales, potentially via a refurbishment stage, or towards another exit route. This is often done by third party employees, who may lack proper training and also follow their own goals, such as rapid processing rather than maximising the retained product value. Products returned in imperfect state, or out of season, are often auctioned off in bulk to third parties ('jobbers') at very low prices. What jobbers do with these large quantities of diverse products in diverse conditions, is largely unknown and subject to speculation. One key issue is whether the use of jobbers conflicts with retailers' Corporate Social Responsibility (CSR) commitments, and risks damaging their legitimacy.

Whilst some pioneering retailers actively engage in the Circular Economy as illustrated in Figure 1, the general change away from a throw-away society is slow, and most retailers are further behind (redacted for review: sustainability article). Returned products seldom undergo any reconditioning / refurbishing / repair; even simply receiving new packaging is often impossible. As shown in (redacted for review: project report), some stores will directly sell imperfect returned products at a reduced price (assuming they carry the returned product in this particular store), but the products that go via the (R)DC usually get auctioned off / go to charity or may even end up in landfill - often unnecessarily. The access to secondary markets has not been sufficiently optimised. 
Figure 1: Circular economy in product returns

Another issue, highlighted by all product returns managers in our case studies, is the general lack of consistent data on returns. Companies are unable to track products sold in store or online through the various returns routes. Any statistics they may have are usually incomplete, fragmented, held by various departments, not consistently monitored, and not reported to senior management level.

Finally, there are also problems on the consumer side. The rise of eCommerce has made it easier to succumb to impulsive and compulsive buying, as it is easy to reverse by returning the products. Recently, illegitimate "borrowing" has also become socially acceptable, be it "wardrobing" (ordering clothes and accessories with the purpose of producing images for Social Media or to attend an event) or buying a large TV for the duration of a sports event / children's bikes for the summer holidays, and then returning the products. With their focus on providing great customer service, many companies struggle to stop these trends, and store assistants are reluctant to confront offending customers.

The reasons why customers return products vary. Understanding them better would allow retailers to take action to reduce return rates, but again, this data are usually not collected consistently. $70 \%$ of returns are indicated as being due to a change of mind, but this number is likely to be wrong. This is because 
'change of mind' is usually the first item in the list and may be selected out of convenience by consumers ticking boxes on their return slip and (R)DC workers hurriedly transferring this data into their computers via a drop-down menu as well as store assistants entering returns into their systems.

\subsection{Recent developments and operational recommendations for retailers}

Since the conclusion of the first research phase, and the communication with retailers about the identified vulnerabilities, some changes have happened: Retailers are trying to address the issues, but do so when the whole system is in movement. Some have started to implement their already existing policies (e.g. no refund without a receipt), being less lenient with customers. Others have taken more drastic steps and received bad publicity for it. For instance, ASOS and Amazon have started to blacklist serial returners who do not keep enough of the ordered products. This emphasizes the importance of customer responsibility.

Some retailers are relying on technologies like RFID tags - recently introduced on each product - to improve their tracking, increasing inventory accuracy as well as reducing opportunities for theft. Being able to determine whether an item was actually sold as claimed by the customer will provide retailers with an advantage, but it does not relieve store assistants from having to confront suspicious customers.

One of the contractually agreed exit routes for products returned to the $(R) D C$ is to be sent back to the supplier / manufacturer. Whilst this is a convenient solution for retailers, manufacturers have now stopped blindly accepting all returns, and are starting to investigate whether or not there is a legitimate reason for the product to be sent back, such as a manufacturing fault.

Product returns need to be championed by senior management, committed to improvement. It is well worth their time, as improvements on product returns directly affect the bottom line. In one of our case companies, small changes to practice, including minimal investment in new systems and handheld technology, had led to savings over four years of $£ 19$ million which was the equivalent of a $4 \%$ increase in net profit. At a net margin of $1 \%$, this was the same increase as would have been incurred from additional sales of around $£ 1.9$ billion over the four years, without adjusting for the cost of the infrastructure needed in case returns are made. It is easier to achieve those savings than to make the additional sales.

Table 1 summarises the next steps for retailers to implement improvements, together with an indication of how difficult these changes might be to implement and a description of the expected impact.

Table 1: Next steps for retailers

\begin{tabular}{|l|l|l|}
\hline Change to implement & Ease of implementation & Expected effect \\
\hline $\begin{array}{l}\text { Enforce existing returns policies } \\
\text { (e.g. no return without a receipt) }\end{array}$ & $\begin{array}{l}\text { Quick, although offending } \\
\text { customers may not like it }\end{array}$ & $\begin{array}{l}\text { Will reduce the number of } \\
\text { returns that should not have } \\
\text { been accepted }\end{array}$ \\
\hline Add RFID tags to each product & $\begin{array}{l}\text { Requires some investment in } \\
\text { technology }\end{array}$ & $\begin{array}{l}\text { Items will be traceable; will } \\
\text { reduce fraud (returns accepted } \\
\text { only with receipt and RFID tag) }\end{array}$ \\
\hline Blacklist repeat returners; & Fairly easy & Reduce fraud; make consumers \\
\hline
\end{tabular}




\begin{tabular}{|l|l|l|}
\hline disable guest checkout & & $\begin{array}{l}\text { think about their own returns } \\
\text { rate }\end{array}$ \\
\hline $\begin{array}{l}\text { Oversight and commitment to } \\
\text { improvement at senior } \\
\text { management level }\end{array}$ & $\begin{array}{l}\text { May require some strategic } \\
\text { restructuring }\end{array}$ & $\begin{array}{l}\text { Major - the company's bottom } \\
\text { line will be affected positively } \\
\text { without the need to generate } \\
\text { additional sales }\end{array}$ \\
\hline $\begin{array}{l}\text { Using cross-functional teams to } \\
\text { manage returns processes }\end{array}$ & $\begin{array}{l}\text { Requires the involvement of } \\
\text { colleagues from various } \\
\text { departments }\end{array}$ & $\begin{array}{l}\text { Major - returns processes will } \\
\text { become more effective and } \\
\text { efficient }\end{array}$ \\
\hline $\begin{array}{l}\text { Systematic use and analysis of } \\
\text { returns codes }\end{array}$ & $\begin{array}{l}\text { Fairly easy, some commitment } \\
\text { to data analysis }\end{array}$ & $\begin{array}{l}\text { Causes of product returns such } \\
\text { as incorrect product } \\
\text { representation online or bad } \\
\text { fitting could be addressed, } \\
\text { hence reducing the returns rate }\end{array}$ \\
\hline $\begin{array}{l}\text { Open-book contracts with third } \\
\text { parties running the (R)DCs }\end{array}$ & $\begin{array}{l}\text { Change of contracts and training } \\
\text { of employees to work towards } \\
\text { maximising the retained sales } \\
\text { value }\end{array}$ & Considerable financial effect \\
\hline
\end{tabular}

\section{Where Operations and Production Management research could make an impact}

One of the reasons why the product returns problem is challenging is its interdisciplinary nature; it spans from customer behaviour control, marketing and advertising, purchasing, supply chain and logistics, customer service, accounting, analytics, strategic operations management, to circular economy, product design, material science, waste management and recycling.

Product returns lead to increased transportation and product waste, both leading to harmful effects on the environment. However, there is also an opportunity to innovate and find new solutions for reducing product returns, influencing consumer behaviours, improving returns systems, and striving towards a more circular economy (remember Figure 1). There is scope for multiple streams of interdisciplinary research to make an impact. Through our case studies, interviews and retailer forum interactions, we identified a number of challenges that need to be tackled to streamline product returns systems; see Table 2.

Table 2 (landscape): Vulnerabilities in product returns systems and suggested approaches to mitigate them; for more details see (redacted for review: project report).

\begin{tabular}{|l|l|l|}
\hline Identified vulnerability & Problem description & Suggested solution \\
\hline $\begin{array}{l}\text { Treating returns as an } \\
\text { asset with strategic } \\
\text { importance }\end{array}$ & $\begin{array}{l}\text { Many of the loss prevention } \\
\text { managers work in isolation. Better } \\
\text { practices were found in companies } \\
\text { where there was discussion and } \\
\text { action between the loss prevention } \\
\text { team, operations and finance. }\end{array}$ & $\begin{array}{l}\text { The potential of returns to generate } \\
\text { savings and income implies that } \\
\text { returns should be treated as assets - a } \\
\text { point noted early in this field by } \\
\text { Rogers et al. (2002) - and that the } \\
\text { function should be regarded as a profit }\end{array}$ \\
\hline
\end{tabular}


Ideally, purchasing and marketing should also be involved, as their decisions lead to the stocking of items that incur returns issues. Whilst reports were used to find the decisions that had resulted in the inventory being carried, there appeared to be little proactive planning and learning between teams.

\section{Poor data management} Retailers typically collect some da
about returned products, but are unable to provide a holistic picture. Different sets of data are held by different departments and cannot be reconciled.

IT systems to manage returns are an essential aspect in dire need of solutions. They currently consist largely of poorly connected internal legacy systems. Issues arise because the transactions that involve returns are recorded in different areas of the company. This makes it very difficult to isolate all the overhead and variable costs associated with returns, making accurate and complete costing of returns an almost impossible task. In addition, we have found that refunds and goodwill payments are given that are difficult to reconcile with actual returns, due to delays in processing between online sales, inventory and store systems. These gaps get known by consumers via social media and other contacts, leading to refund fraud issues. Companies originating from catalogue sales or those originally set up as pure online businesses generally do better, as their business models and IT systems are more streamlined. Retailers with physical stores aiming at becoming omnichannel businesses rather than a cost centre. In turn, an executive officer should have oversight of the function and be responsible for reporting on returns to the board, which should offer monitoring and evaluation.

Returns streams should be logged, monitored and reported to senior management, such that issues with individual channels can be identified and addressed.

Apps are being developed to help customers select the right size, either through linking clothing sizes of different brands to body measures, attempting to assess the true fit of clothing on persons of different shapes, or - more futuristic - through the use of 3D scanning technology. Currently, these apps are not good enough yet, but the potential impact is significant.

Similarly, software packages are being launched for better tracking of returned products and linking them to issued refunds, avoiding double refunds. This is necessary because especially companies with a strong customer service focus often issue a refund, and sometimes even an additional goodwill payment to compensate for the "trouble", when a complaint is raised or a product is returned to a store (or to a drop-box I parcel shop). At this stage, products are often not verified yet (or have not been received, in the case of a phone complaint), and once they reach the (R)DC, another refund might be triggered. Easy-to-use IT systems that 
usually struggle considerably. The rate of returns is affected by the accuracy of descriptions of products online as well as confusions arising when goods are returned, especially if the retailer allows customers to check out as guests rather than setting up an account.

Complexity of returns processes
Organising and managing returns systems is a highly complex challenge that needs dedication. Many companies are overwhelmed and unable to tackle this internally.

\begin{tabular}{|l|l|} 
& \\
& \\
\hline $\begin{array}{l}\text { Understanding and } \\
\text { directing consumer } \\
\text { behaviours }\end{array}$ & $\begin{array}{l}\text { Consumers have diverse reasons } \\
\text { for their behaviours, yet there are } \\
\text { no specific control mechanisms to } \\
\text { direct consumers and help them } \\
\text { make informed choices. For } \\
\text { instance, consumers currently have } \\
\text { no information on the } \\
\text { environmental and economic } \\
\text { impact of their delivery and return } \\
\text { option choices - all they know is } \\
\text { whether they have to pay. }\end{array}$ \\
\hline
\end{tabular}

\begin{tabular}{|l|l} 
& \\
\hline Conflicts with Corporate & There are potential conflicts
\end{tabular}

Conflicts with Corporate Social Responsibility commitments
There are potential conflicts between what happens to returned products, notably in through the hands of jobbers, and corporate social responsibility commitments, can reliably link the various stages of the process, which may be in the hands of different companies (retailers, logistics providers, warehouse operators), are necessary.

Third party returns service providers are emerging, offering to take care of the whole process. Using one of them could be an advantage, as these companies specialise in product returns, and are therefore expected to excel at it. However, it also means that the retailer is outsourcing yet another area that might be critical for the business, and taking the right decision is of strategic importance.

Furthermore, there is great scope for interdisciplinary research linking changes in company practices across the field, to changes in consumer behaviour in relation to online shopping.

A systematic implementation and analysis of return codes in conjunction with behavioural studies would provide a deeper understanding of why certain groups of consumers frequently return products and would allow retailers to guide consumer behaviours. This could include optimising how products are represented online, adjusting sizing and fitting of clothing, and better suiting business proposals (e.g. a membership fee for access to fashion items) for certain shoppers.

More sustainable ways of dealing with unwanted products need to be identified, and products need to be designed with sustainable end-of-life solutions in mind. Jobber practices need to be scrutinised. 


\begin{tabular}{|l|l|l|}
\hline $\begin{array}{l}\text { More sustainable } \\
\text { business models }\end{array}$ & $\begin{array}{l}\text { Current business models are linear } \\
\text { and focused on increasing } \\
\text { consumption. }\end{array}$ & $\begin{array}{l}\text { More sustainable business models are } \\
\text { circular, may be based on access } \\
\text { rather than ownership, and involve } \\
\text { retailers and manufacturers to ensure } \\
\text { that jobs are conserved. }\end{array}$ \\
\hline $\begin{array}{l}\text { Refinement of the } \\
\text { returns cost calculator }\end{array}$ & $\begin{array}{l}\text { A first version has been developed } \\
\text { and tested with a small number of } \\
\text { retailers; publication forthcoming. }\end{array}$ & $\begin{array}{l}\text { Further costing models are needed, } \\
\text { including a way to quantify the } \\
\text { damage to the environment through } \\
\text { wasted resources, and the cost to } \\
\text { society of lost jobs and bankrupt } \\
\text { businesses. }\end{array}$ \\
\hline
\end{tabular}

\subsection{Lean product returns systems}

The organisations we examined all apply the principles of Lean management, such as just-in-time, customer first and waste reduction, to their forward supply chain management and retail operations. What comes out of our work is that returns processes are not yet Lean. In fact, we found that there is little research on Lean returns processes generally and that is perhaps not surprising. If a forward Lean thinking system is working, then there should be zero defects and zero waste, and a culture of getting it right the first time - in other words, no returns! But returns are a fact of life in retail and part of doing business. Lean returns processes are needed that can be integrated with the established Lean thinking sales systems in place. We could also call this 'Lean thinking reverse logistics' and that is helpful, as thinking in reverse is needed for this issue.

This is a key area for development in reverse logistics and product returns. For example, while no-one wishes to lose the customer first ethos in retailing, when designing Lean reverse logistics, the simple observation that in returns the retailer becomes the customer needs to be adopted. A focus on effectively delivering value to the customer returning the goods in the reverse logistics setting means also thinking about "how can the retailer as an organisation get value from the returns process?". Another point for lateral thinking in designing Lean reverse logistics is that for product returns, we have a push system based on supply rather than a pull system based on demand. To some extent, this supply can be forecast based on previous behaviours but it is not entirely predictable. However, we can control how product is pushed through exit routes, and therefore there is some scope to make a push system flow back into the pull system in sales.

There are a very few consultancy studies that examine the notion of Lean returns management or Lean returns logistics, including Four Principles (2018). The challenge open to academic researchers is to conceptualise and create models for the cost-benefits of Lean management applied to product returns. Research consultancy exercises can identify sources of wasted resources and effort, and the steps that can be reduced. The critical foundations for why, where and when such systems should be deployed, is open for debate and creative evaluation. The questions relate to the meanings of customer satisfaction in this context; turning a pull system into a push system; what constitutes waste and getting things right first time in reverse logistics.

\section{Which methods and why}

Product returns research typically uses a mixed methods approach including multiple case studies. In the future, we are looking to use surveys as well as big data analysis (that is, if the data can be obtained) to 
obtain more generalisable information. There is scope to use benchmarking and to develop environmental management accounting techniques that encourage managers to better understand the opportunities for circular economy initiatives in organisations. Furthermore, strategic business models should be developed, aiming to reduce product returns, simplify transactions, reduce transportation and product waste, and are generally more sustainable socially, ecologically and economically. Solutions will involve strategic operations, strategic planning, monitoring and evaluation.

Furthermore, transactional theories could help explain the phenomenon of soaring product returns from the perspective of retailers and manufacturers, and behavioural theories from the perspective of consumers. Some work has been done in marketing, our team has started to explore experience-seeking and compulsive shopping behaviours.

Generally, the research topic lends itself to qualitative data collection and analysis that investigate human behaviours within systems and where practices are constrained by embedded norms. The unintended consequences of changing practices in retail (such as offering unlimited free returns) and their impact on organisational behaviours lends itself to psychological analysis and social theory analysis. However, there is scope for quantitative work in assessing and evaluating cost data, where available, and in building operational research models for more effective reverse logistics within organisations. We have seen an interest from companies to work with academics to develop understanding and interventions across all these areas.

\section{Summary and conclusion}

Seemingly simple and often just considered to be a negligent cost of doing business, retail returns have turned out to be a proverbial "can of worms". There are many major, multi-layered issues that require interdisciplinary, cross-functional teams to solve them. Research on product returns is an emerging area of research with many opportunities to do applied research and achieve considerable impact on society, the environment, the economy whilst contributing to the academic body of knowledge. Manufacturers, logistics providers and retailers could benefit from receiving guidance on how to implement Lean concepts in product returns systems. Streamlining returns processes would mitigate the current frustration of employees dealing with product returns, reduce the environmental impact, and help companies become more profitable again.

\section{Acknowledgements}

The authors thank the [redacted for review - association of retailers] for their ongoing support.

\section{References}

Four Principles (2018). Lean Reverse Logistics. Available online: https://fourprinciples.com/ourexpertise/functional-solutions/reverse-logistics/

Institute for European Environmental Policy (2019, 28 November). Tackling over-consumption: A key challenge for the European Green Deal. Available online: https://ieep.eu/news/tackling-over-consumptiona-key-challenge-for-the-european-green-deal

Ram, A. (2016). UK retailers count the cost of returns. Financial Times, 27 January. Available online: https://www.ft.com/content/52d26de8-c0e6-11e5-846f-79b0e3d20eaf 
Rogers, D., Lambert, D., Croxton, K. and García-Dastugue, S. (2002). The Returns Management Process. International Journal of Logistics Management, 13(2), 1-18.

https://doi.org/10.1108/09574090210806397

Schiffer, J. (2019). The unsustainable cost of free returns. Vogue Business, available online: https://www.voguebusiness.com/consumers/returns-rising-costs-retail-environmental

Speights, D. (2013). Return Rate Miscalculations Impact Retail Chains Nationwide. White paper, Appriss Retail, available online: https://appriss.com/retail/wp-content/uploads/sites/4/2017/02/wp_TRE4015WhitePaper-ReturnRateMiscalculations March2013.pdf 


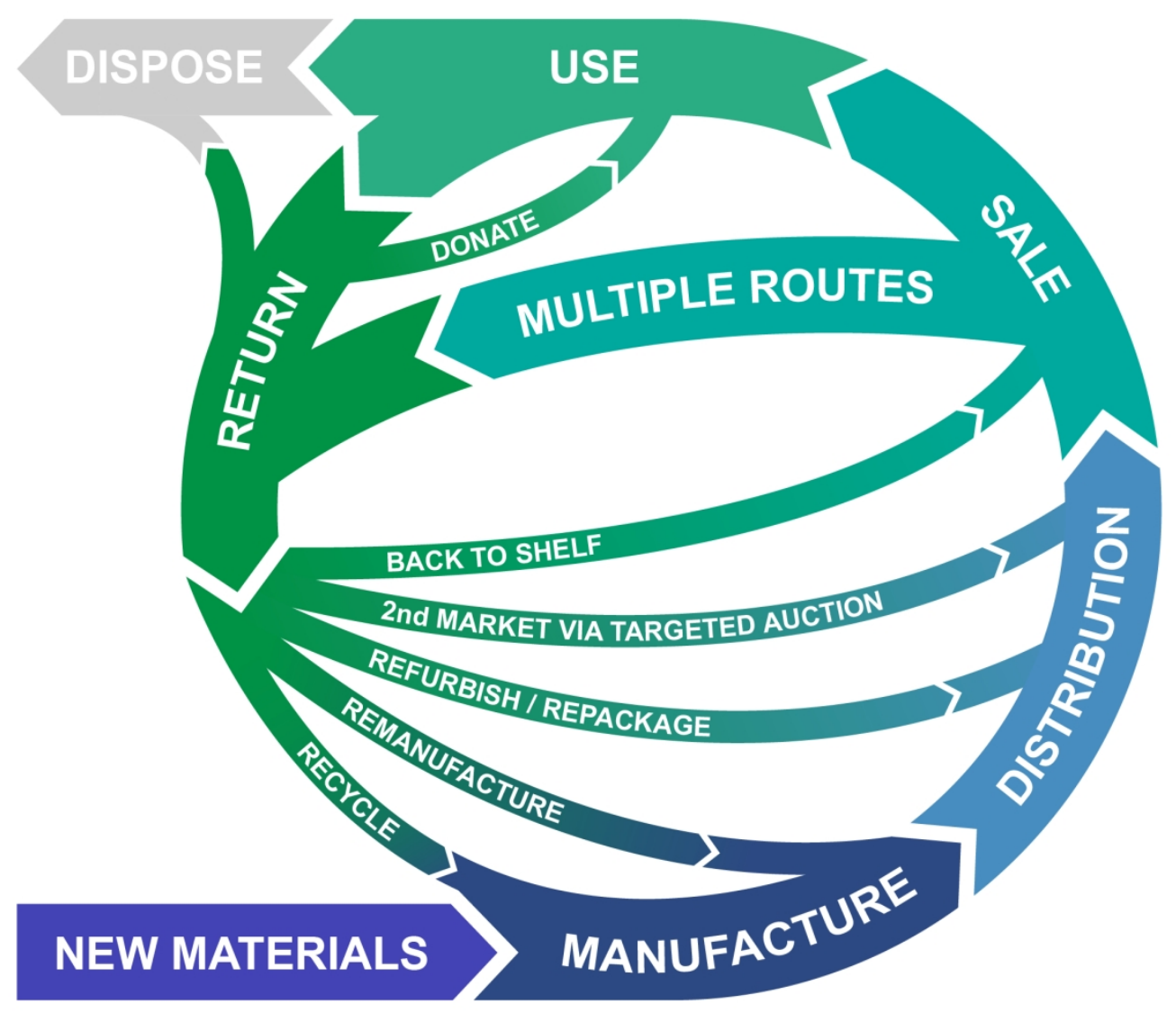

